\title{
Process of converting human hair into hollow carbon filament for electrochemical capacitor
}

Guilherme Charles Blanco ${ }^{1}$, Manuella Gobbo de Castro Munhoz ${ }^{1}$, Aline Castilho Rodrigues ${ }^{1}$, Andrés Cuña ${ }^{2}$, Ana Claudia Pina ${ }^{2}$, Jossano Saldanha Marcuzzo ${ }^{3}$, Mauricio Ribeiro Baldan ${ }^{1}$

\footnotetext{
${ }^{1}$ Instituto Nacional de Pesquisas Espaciais, Avenida dos Astronautas, 1758, CEP: 12227-010, São José dos Campos, São Paulo, Brasil.

${ }^{2}$ Universidad de la República - DETEMA-Área Fisicoquímica, Avenida General Flores, 2124, CEP: 11800, Montevideo, Uruguay.

${ }^{3}$ JMHP - Consultoria em Materiais Ltda, Rua Glauber Rocha, 187, CEP: 12301-600, Jacareí, São Paulo, Brasil. e-mail: blanco.sjc@gmail.com,manuellagobbo@gmail.com, alinerodrigues_1@msn.com, acunasuarez@gmail.com, acpina@fq.edu.uy, jossano@gmail.com, mrbaldan@gmail.com
}

\begin{abstract}
Carbon material is the largest material used as electrode on advanced energy storage devices. The modern lifestyle requires more energy, consequently, more smart energy use and efficient devices are needed. The constant evolution of materials technologies looking for green material and renewable raw material, that have minimal impact on the environment, is one of the most important subjects studied in recent years. The scientific and industry community are paying more attention to new forms of carbon such as nanotubes, graphene, and activated carbon fiber. The purpose of this work is to convert human hair into a hollow carbon filament to be used as a supercapacitor electrode. The human hair needs 3 stages to be converted into carbon filament: textile manufacture, oxidation, and carbonization. The electrochemical behavior was analyzed in a threeelectrode electrochemical cell system with $2 \mathrm{M}$ of $\mathrm{H}_{2} \mathrm{SO}_{4}$ electrolyte medium. The behavior of the electrode was characterized electrochemically by galvanostatic charge/discharge curves, cyclic voltammetry, and electrochemical impedance spectroscopy, showing $163 \mathrm{~F} \mathrm{~g}^{-1}$ of a maximum value of specific capacitance.
\end{abstract}

Keywords: Residue. Human hair. Felt. Carbon filament. Supercapacitor.

\section{INTRODUCTION}

It is common to find the word hair related to areas of health, aesthetics, and beauty. On the other hand, when it is cut, it becomes a material considered useless and, therefore, it is discarded and disposed as waste [1,2]. Brazil is a country with a very high ethnic mix [3] and, as a result, there is a great diversity of hair types. Hair can be classified into three major geo-racial groups: Afro, Asian, and Caucasian as shown in Figure 1a or can be further classified into up to 8 types according to the curvature of the hair, using the Segmentation Tree Analysis Method (STAM), shown in Figure 1b [4, 5]. 
a

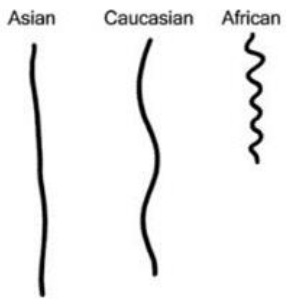

b
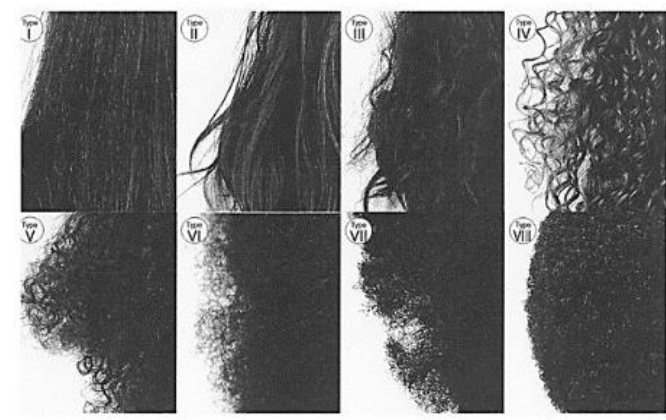

Figure 1: a) human hair shape from different geo-racial origins (Adapted from ROBBINS, 2012) and b) illustration of the appearance of eight types of curly hair [5].

The hair fiber is divided into three main parts: medulla (present in some cases), cortex, and cuticle, as shown in Figure 2. The main difference in each region is the type of protein present in each region $[4,6,7]$. The interior content of the capillary fiber, constituted by the cortex and sometimes by a medulla, has a structure susceptible to volatility when subjected to high temperatures $\left(>200{ }^{\circ} \mathrm{C}\right)[8,9]$.

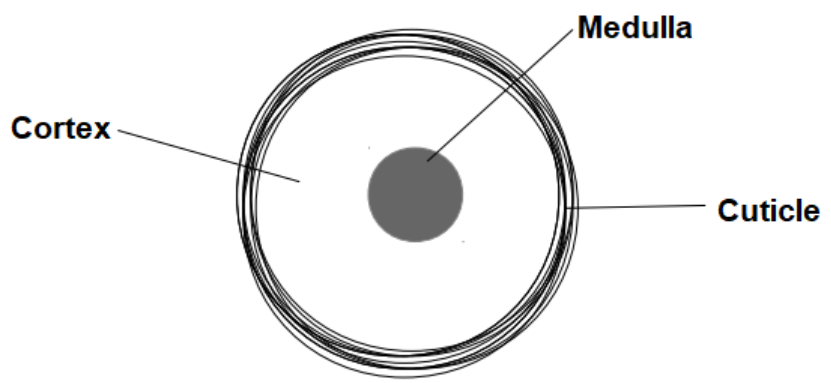

Figure 2: Schematic representation of a cross-section of a capillary fiber with bone marrow (Adapted from BLANCO, 2019 [8]).

Therefore, the residue generated in beauty salons and barbershops is heterogeneous. According to an estimate presented by Dinâmica Ambiental (a company that collects discarded hair in São Paulo by the Beleza Verde project in partnership with the NGO Matter of Trust | Eco-Enthusiasts for Renewable Resources), about $100 \mathrm{~kg}$ of hair waste is collected annually in 40 salons. Extrapolating this number to 600,000 (approximate number of salons registered in Brazil) [10, 11], there is a total of 1,500,000 kg/year. According to the Brazilian Association of Technical Standards (Associação Brasileira de Normal Técnicas - ABNT), hair can be classified as class II B - Inert, non-hazardous solid waste, and for this reason, it is sent to landfills [12].

Many researchers have as their scientific motivation the search for alternatives to minimize the volume of waste that reaches the landfill. In this way, the number of works related to the reuse and use of organic materials as precursors of carbonaceous materials is increasing [9, 13-17]. Among the various carbonaceous materials, non-structural carbon fibers $(\mathrm{CF})$ has special characteristics when compared to other carbon materials [18]. Obtaining CF involves heat treatments of the precursor, organic or synthetic, at high temperatures in the presence of different gases. Therefore, this work aims at the use of human hair from residues of beauty salons, making it an alternative precursor material for the manufacture of carbon material and its application as a supercapacitor electrode. Carbon materials are one of the most promising electrodes for supercapacitors with high power densities and long cyclic lives. Currently, there has been a special interest in carbon-based materials with tunable specific area, chemical stability and excellent charge-carrier mobility. In 
this study we demonstrate that human hair possesses potential advantages for applications as supercapacitor electrodes.

\section{MATERIALS AND METHODS}

Natural reddish brown $(\mathrm{CN})$ Caucasian hair and brown Caucasian hair, with any red synthetic color (CC), were used to make the felts. All hair was supplied by Studio Tata Blanco. With the aid of a polyurethane sponge and a hand felting needle, the felts were prepared. The first felt containing only $\mathrm{CN}$ and the second felt containing only CC, each hair supplied by the same head. The process employed is known as handmade needle felting.

The hair felts in natura (in), that are, without any type of heat treatment, were cut into a rectangular shape, with approximately $45 \times 30 \mathrm{~mm}$. The samples were oxidized and carbonized separately in an EDG tubular oven, model HI40. The oxidation was carried out at $300{ }^{\circ} \mathrm{C}$ for $2 \mathrm{~h}$ at a rate of $20{ }^{\circ} \mathrm{C} / \mathrm{min}$ and the carbonization at $900{ }^{\circ} \mathrm{C}$ for $20 \mathrm{~min}$ at a rate of $5{ }^{\circ} \mathrm{C} / \mathrm{min}$. After this stage, the samples were named CNin and $\mathrm{CC}$ in, for samples without heat treatment and $\mathrm{CNC}$ and $\mathrm{CCC}$, for oxidized and carbonized samples.

The in natura and carbonized hair felts were characterized by Scanning Electron Microscopy with Field Emission, a TESCAN model VEGA. The samples were also characterized by Raman spectroscopy technique, a Horiba Scientific model Labram Hr Evolution, using the $514.6 \mathrm{~cm}^{-1}$ laser, from to LABAS/INPE. To determine the surface area $\left(\mathrm{S}_{\mathrm{BET}}\right)$ were used a Beckman Coulter adsorptiometer model SA3100. In addition, cyclic voltammetry measurements and galvanostatic charge/discharge tests were performed on an Autolab potentiostat/galvanostat, model PGSTAT302N, to analyze the behavior of these felts as electrodes applied to energy storage devices. The electrochemical tests were performed using a three-electrode cell, with a platinum plate as a counter electrode, and $\mathrm{KCl}$ saturated $\mathrm{Ag} / \mathrm{AgCl}$ electrode was used as reference. All the measurements were carried out using $2 \mathrm{~mol} \mathrm{~L}^{-1} \mathrm{H}_{2} \mathrm{SO}_{4}$ as the electrolyte. The cyclic voltammetry was carried out in the potential window of $0.0-1.0 \mathrm{~V}$ at a scan rate of $2 \mathrm{mV} \mathrm{s}^{-1}$, and the galvanostatic charge/discharge curves were conducted at the potential window between 0.0 and $1.0 \mathrm{~V}$ with a current range of $2,5,10$, and 10 mA.

\section{RESULTS E DISCUSSIONS}

\subsection{Morphological analysis}

Figures $3 \mathrm{a}$ and $3 \mathrm{~b}$ show micrographs of the CNin and CCin felts, respectively. It is possible to observe preserved structures, typical of healthy hair, that is, the cuticular cells (overlapping outer layers) and the cortex (solid interior) are whole and well defined, besides, it is noted that in these cases, the absence of the cord (intermittent cylinder of resistant protein content, which may or may not exist in the center of hair and hair).

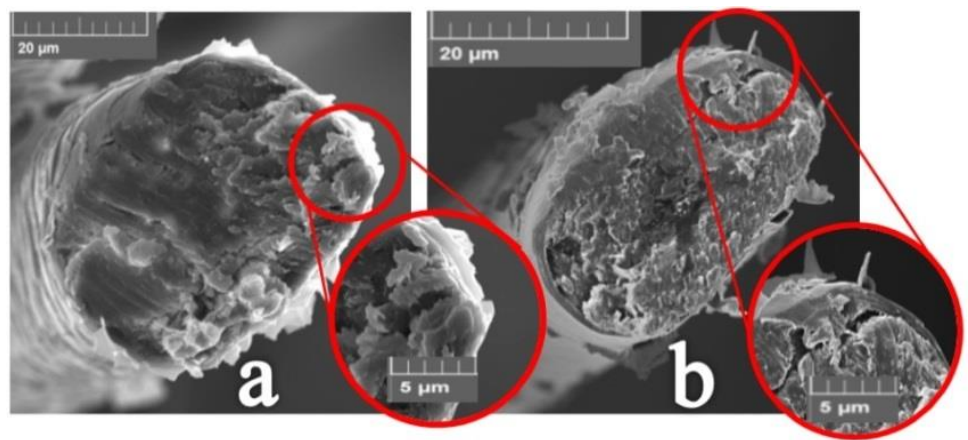

Figure 3: Felt filaments of (a) CNin e (b) CCin.

Figures $4 \mathrm{a}$ and $4 \mathrm{~b}$ show the micrographs of the felt filaments, CNC and CCC respectively. By comparing them with Figures $3 \mathrm{a}$ and $3 \mathrm{~b}$ there is a notable absence of the cortex inside the filament, a predicted consequence, since the oxidation process volatilizes some structures, making the hollow filament tube-like [8, 9, 19]. Pramanick et al, in similar work, used human hair for the manufacture of sensors and obtained a hollow filament after carbonization or pyrolysis. They also associate this fact with the loss of the cortex, leaving only the cuticular structure (rich in fixed carbon) $[8,20]$. 


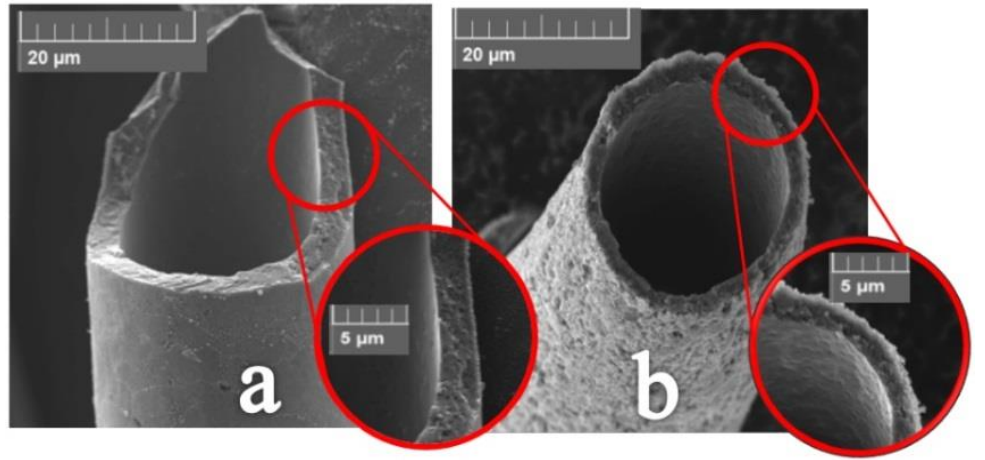

Figure 4: Felt filaments of (a) CNC e (b) CCC.

It is possible to observe that the CCC felt filament obtained a different rougher, when compared to $\mathrm{CNC}$, suggesting a different pore size/type distribution and possibly a more porous surface for each sample, an important characteristic for the use of carbon materials in energy storage devices.

\subsection{Raman analysis}

Raman spectroscopy is widely used for investigating carbon materials. The CNC and CCC felt were subjected to Raman scattering spectroscopy analysis, for a better understanding of the material's graphitic structure. Due to the sensitivity of the laser used $\left(514 \mathrm{~cm}^{-1}\right)$ to different carbon structures, it is possible to identify a carbonaceous material [21].

In the first-order region, the E2g vibration modes of the samples $\mathrm{CNC}$ and $\mathrm{CCC}$ are attributed to the vibration of carbons within the polyaromatic structure. The Raman signal of all carbonaceous materials is well known. Carbonaceous materials exhibit characteristic peaks in the range from 1000 to $1800 \mathrm{~cm}^{-1}$. The bands found in these ranges are known as D (1200 to $1400 \mathrm{~cm}^{-1}$ ) and $\mathrm{G}$ (1500 to $1600 \mathrm{~cm}^{-1}$ ) bands (D band for defects, and $\mathrm{G}$ band for graphite) [22].

Figure 5 shows the first-order Raman spectra of carbonized CNC and CCC felts. Two main peaks can be observed at approximately 1335 and $1600 \mathrm{~cm}^{-1}$, characteristic of carbonaceous materials. The intensities of the disorder ( $\mathrm{D}$ band) and order ( $\mathrm{G}$ band graphite) provides a standard parameter to quantifying disorder. Since the intensities are very similar quantifying disorder is about the same.

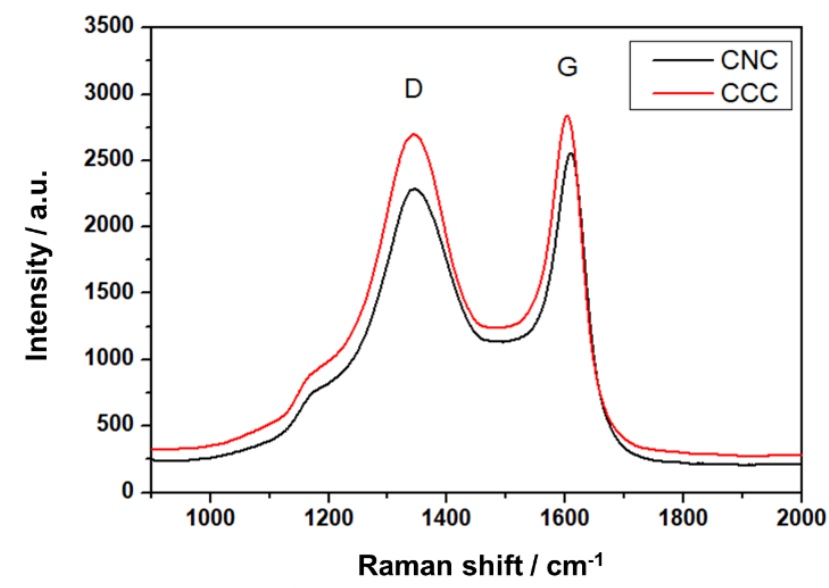

Figure 5: Raman spectrum of $\mathrm{CNC}$ and $\mathrm{CCC}$ felts after the oxidation and carbonization process.

\subsection{Electrochemical analysis}

Figure 6 shows the voltammogram $(\mathrm{CV})$ of the CNC and CCC felts. Current density J (measured in Ampere/gram) is related to the number of charges stored in reversible charge/discharge processes. The shape of the (rectangular) curve is related to non-faradaic processes and the more rectangular the closer to an ideal capacitor [23].

It is possible to identify two major contributions to the specific capacitance. The double layer capacitance (EDLC), which is a major associated with typical rectangular shape, and the presence of pseudocapacitance which is originated at the electrode surfaces where reversible redox reactions occur. 
Therefore, the CV curves of CNC and CCC exhibited a contribution from EDLC and pseudocapacitance for the total capacitive performance.

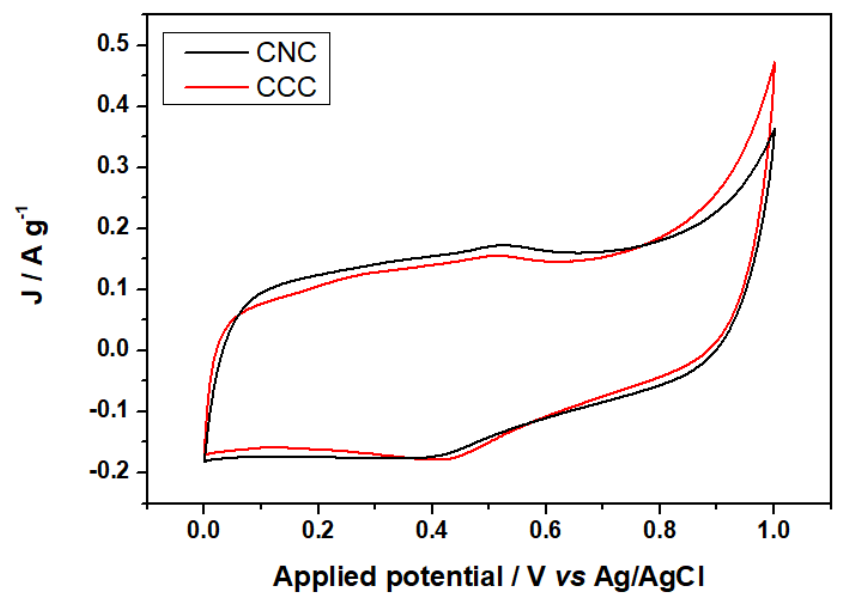

Figure 6: Cyclic voltammetry of CNC and CCC samples.

The galvanostatic charge/discharge curves provide data for calculating the specific capacitance $\left(C_{S}\right)$ of the electrodes, according to Equation 1 [24].

$$
C_{S}=i \cdot t_{d} / m \cdot \Delta V
$$

Where: $\Delta i$ is the sum of charge/discharge currents, $t_{d}$ it is discharge time, $m$ is the electrode mass, and $\Delta V$ is the difference between the last charge potential and the first discharge potential.

Figure 7 shows the values calculated for different current densities. It is possible to notice that, the samples have very similar behavior, as observed in cyclic voltammetry. The CNC had the highest $C_{s}$ value, $163 \mathrm{Fg}^{-1}$, and CCC with $146 \mathrm{Fg}^{-1}$ of $C_{s}$. Another important issue is the surface area. CNC presents $697 \mathrm{~m}^{2} \mathrm{~g}^{-1}$ and CCC $235 \mathrm{~m}^{2} \mathrm{~g}^{-1}$ of surface area, which can justify the $C_{s}$ values of the samples. The values of specific capacitance for CCC and CNC are comparable with literature, when we compare with other carbon electrodes materials analyzed in $2 \mathrm{~mol} \mathrm{~L}^{-1} \mathrm{H}_{2} \mathrm{SO}_{4}[25,26]$. There are few studies using pyrolyzed and non-pyrolyzed human hair for supercapacitor applications. However, these studies confirm that human hair can be used as supercapacitor electrodes [27-29].

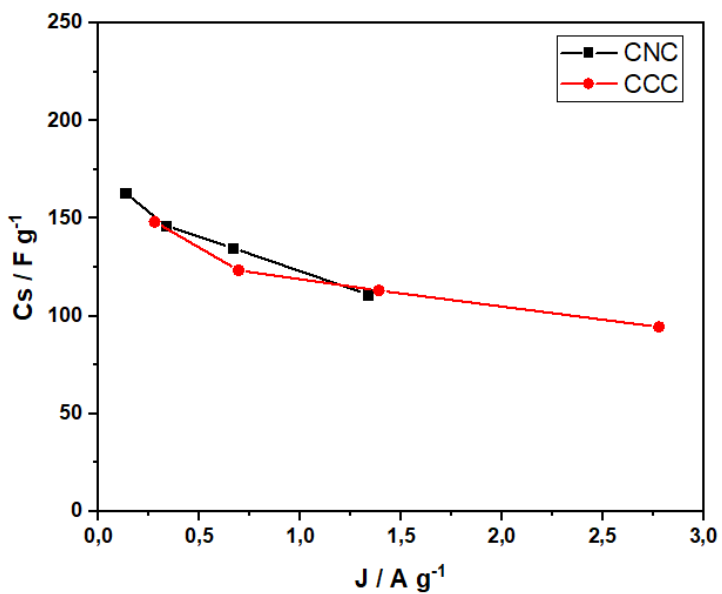

Figure 7: Specific capacitance vs. current density applied. 


\section{CONCLUSIONS}

The felts of natural brown and colored Caucasian hair with artificial coloring maintained the threedimensional structure and the cortex was lost, making it a hollow filament felt in the shape of a tube. The analysis of Raman spectroscopy showed characteristic peaks of carbonaceous materials (bands D and G), with this, it can be said that the felts CNC and CCC became carbon filament. The electrochemical analysis showed a great performance as an energy storage device, with specific capacitance values of 163 and $146 \mathrm{Fg}^{-}$

${ }^{1}$ for $\mathrm{CNC}$ and $\mathrm{CCC}$, respectively. These results demonstrate that human hair can be considered an alternative precursor material for the manufacture of carbon filament.

\section{ACKNOWLEDGMENTS}

The authors would like to thank CAPES, FINEP, and INPE for funding and support.

\section{BIBLIOGRAPHY}

[1] OLIVEIRA, R.A.G., ZANONI, T.B., BESSEGATO, G.G., et al. THE CHEMISTRY AND TOXICITY OF HAIR DYES. Quim. Nova. 2014;X:1-10.

[2] KUMAR, S., BHATTACHAR,Y.Y.A.J.K., VAIDYA, A.N., et al. Assessment of the status of municipal solid waste management in metro cities, state capitals, class I cities, and class II towns in India: An insight. Waste Manag. 2009;29:883-895.

[3] KEHDY, F.S.G., GOUVEIA, M.H., MACHADO, M., et al. Origin and dynamics of admixture in Brazilians and its effect on the pattern of deleterious mutations. Proc. Natl. Acad. Sci. 2015;112:8696-8701.

[4] ROBBINS, C.R. Chemical and physical behavior of human hair, 5th edition. Chem. Phys. Behav. Hum. Hair, 5th Ed. 2012.

[5] METTRIE, R. L.A., SAINT-LÉGER, D., LOUSSOUARN, G., et al. Shape Variability and Classification of Human Hair: A Worldwide Approach. Hum. Biol. 2007;79:265-281.

[6] BHUSHAN, B. Biophysics of Human Hair: Structural, Nanomechanical, and Nanotribological Studies. New York: Springer; 2010.

[7] JOLLÈS, P., ZAHN, H., HÖCKER, H. Formation and Structure os Human Hair. 1st editio. Berlin: Birkhäuser Verlag; 1997.

[8] BLANCO, G.C., RODRIGUES, A.C., MARCUZO, J.S., et al. Preparação de cabelo caucasiano como material carbonoso. Rev. Bras. Apl. Vácuo. 2019;38:10.

[9] CHEN, W., LIU, X., HE, R.L., et al. Activated carbon powders from wool fibers. Powder Technol. 2013;234:76-83.

[10] SCHREIDER, S.M. Relação entre os determinantes de satisfação dos clientes de salão de beleza baseado no modelo de Tinoco (2011): um estudo na cidade de Juiz de Fora (MG) clientes em serviços de salão de beleza. Universidade Federal de Juiz de Fora; 2018.

[11] SEBRAE. Práticas de empreendedorismo para salões de beleza no brasil. 2016. p. 95.

[12] Associação Brasileira de Normas Técnicas. Resíduos sólidos - Classificação. Rio de janeiro: 31/05/2004; 2004. p. 0-71.

[13] MARSH, H., RODRÍGUEZ-REINOSO, F. Activation Processes (Thermal or Physical ). Act. Carbon. 2006;2:243-321.

[14] PHAN, N.H., RIO, S., FAUR, C., et al. Production of fibrous activated carbons from natural cellulose (jute, coconut) fibers for water treatment applications. Carbon N. Y. 2006;44:2569-2577.

[15] SOTO, M.L., MOURE, A., DOMÍNGUEZ, H., et al. Recovery, concentration and purification of phenolic compounds by adsorption: A review. J. Food Eng. 2011;105:1-27.

[16] SUZUKI, M. Activated carbon fiber: Fundamentals and applications. Carbon N. Y. 1994;32:577-586.

[17] TĚŠINOVÁ, P. Advances in Composite Materials - Analysis of Natural and Man-Made Materials. 1st ed. Těšinová P, editor. Rijeka, Croatia: Intech Open; 2011.

[18] NEWCOMB, B.A. Processing, structure, and properties of carbon fibers. Compos. Part A Appl. Sci. Manuf. [Internet]. 2016;91:262-282. Available from: http://dx.doi.org/10.1016/j.compositesa.2016.10.018.

[19] PINA, A., AMAYA, A., MARCUZZO, J.S., et al. Supercapacitor Electrode Based on Activated Carbon Wool Felt. C. 2018;24:12. 
[20] PRAMANICK, B., CADENAS, L.B., KIM, D.M., et al. Human hair-derived hollow carbon microfibers for electrochemical sensing. Carbon N. Y. [Internet]. 2016;107:872-877. Available from: http://dx.doi.org/10.1016/j.carbon.2016.06.095.

[21] AMARAL JUNIOR, M.A., MATSUSHIMA, J.T., REZENDE, M.C., et al. Production and Characterization of Activated Carbon Fiber from Textile PAN Fiber. J. Aerosp. Technol. Manag. [Internet]. 2017;9:423-430. Available from: http://www.jatm.com.br/ojs/index.php/jatm/article/view/831.

[22] JUNIOR, M.A.A. Obtenção e Caracterização de Compósitos a Base de Fibra de Carbono e Fibra de Carbono Ativada Aplicados a Materiais Absorvedores de Radiação Eletromagnética na faixa de frequência de 8,2 à 12,4GHz (Banda X). Instituto Nacional de Pesquisas Espaciais - INPE; 2018.

[23] RODRIGUES, A.C., SILVA, E.L., QUIRINO, S.F., et al. Ag@Activated Carbon Felt Composite as Electrode for Supercapacitors and a Study of Three Different Aqueous Electrolytes. Mater. Res. [Internet]. 2018;22:1-6. Available from: http://dx.doi.org/10.1590/1980-5373-MR-2018-0530.

[24] RODRIGUES, A.C., MUNHOZ, M.G.C., PINHEIRO, B.S., et al. N- activated carbon fiber produced by oxidation process design and its application as supercapacitor electrode. J. Porous Mater. [Internet]. 2019;27:141-149. Available from: https://doi.org/10.1007/s10934-019-00799-7.

[25] MATSUSHIMA, J.T., RODRIGUES, A.C., MARCUZZO, J.S., et al. 3D-interconnected framework binary composite based on polypyrrole/textile polyacrylonitrile-derived activated carbon fiber felt as supercapacitor electrode. J. Mater. Sci. Mater. Electron. [Internet]. 2020;31:10225-10233. Available from: https://doi.org/10.1007/s10854-020-03568-4.

[26] RODRIGUES, A.C., MUNHOZ, M.G.C., PINHEIRO, B.S., et al. N-activated carbon fiber produced by oxidation process design and its application as supercapacitor electrode. J. Porous Mater. 2019;

[27] SI, W., ZHOU, J., ZHANG, S., et al. Tunable N-doped or dual N, S-doped activated hydrothermal carbons derived from human hair and glucose for supercapacitor applications. Electrochim. Acta [Internet]. 2013;107:397-405. Available from: http://dx.doi.org/10.1016/j.electacta.2013.06.065.

[28] ZHAO, J., GONG, J., ZHOU, C., et al. Utilizing human hair for solid-state flexible fiber-based asymmetric supercapacitors. Appl. Surf. Sci. 2020;508:1-9.

[29] LIU, W., FENG, K., ZHANG, Y., et al. Hair-based flexible knittable supercapacitor with wide operating voltage and ultra-high rate capability. Nano Energy [Internet]. 2017;34:491-499. Available from: http://dx.doi.org/10.1016/j.nanoen.2017.03.022.

\section{ORCID}

Guilherme Charles Blanco

Manuella Gobbo de Castro Munhoz

Aline Castilho Rodrigues

Andrés Cuña

Ana Claudia Pina

Jossano Saldanha Marcuzzo

Mauricio Ribeiro Baldan https://orcid.org/000-0001-9859-6049

https://orcid.org/0000-0002-3593-1919

https://orcid.org/0000-0003-2213-4651

https://orcid.org/0000-0002-1343-2772

https://orcid.org/0000-0002-9141-9047

https://orcid.org/0000-0003-2326-399X

https://orcid.org/0000-0001-7605-1064 